\title{
IN A NEW LIGHT
}

\section{Career opportunities.}

\section{BY S. R. ALGERNON}

CC

Lucifer," said Ned Goodman, sotto voce, as he knelt at a stone altar in a clearing far from town. "Take corporeal form. Appear before me. Offer me your power and I will do as you command."

Goodman placed his hands on an ironbound codex that rested on the altar. Soon, he thought, there will be no more weekends running focus groups for toothpaste and deodorant. Soon, he would wield real power.

Goodman had studied every known ancient language, but the markings on the pages meant nothing to him. The phonetic transcription - on foolscap and weighed down with a rock - had come from a deranged monk of a disgraced order. He had said - among his more lucid ravings — that Hephaestus had forged the codex aeons ago.

Goodman read the incantation. As he did, the earth shook, and the ground on the other side of the altar collapsed into a molten pool. Stray tufts of grass near its edge caught fire. The air stank of sulfur, and it stung Goodman's eyes. A brilliant column of liquid metal oozed up from the pool, taking on a red glow as it cooled. It ballooned out on top like a mushroom or a jellyfish. Flames erupted from its surface, as if the protuberance wore a corona or a ring of horns.

"Are you Lucifer?" asked Goodman.

"You might say I am a servant thereof." The glowing form grinned, revealing a tongue of flame behind pointed teeth. It extended a hand, sheathed in flame.

"Follow me. Lucifer awaits."

"Follow you? Where?"

"To a world of fire. You shall bathe in acid under the weight of a stormy, sulfurous sky."

Goodman shrank back.

"I know you serve the Prince of Darkness and all," said Goodman, "and I don't mean to be impertinent, but aren't you supposed to grant me fearsome powers before dragging me off to perdition?"

"Powers?" The agent of Lucifer's smile faded. "We have geothermal power, if that's what you mean."

"Aren't I supposed to get a chance to do some sinning first?"

"Are you that monk that's been bothering us? Look. We told you last time..."

Discordant howls from beyond the portal drowned out the rest of the reply. A spray of shimmering metal drenched the agent from the right side, dulling the glow of its horns

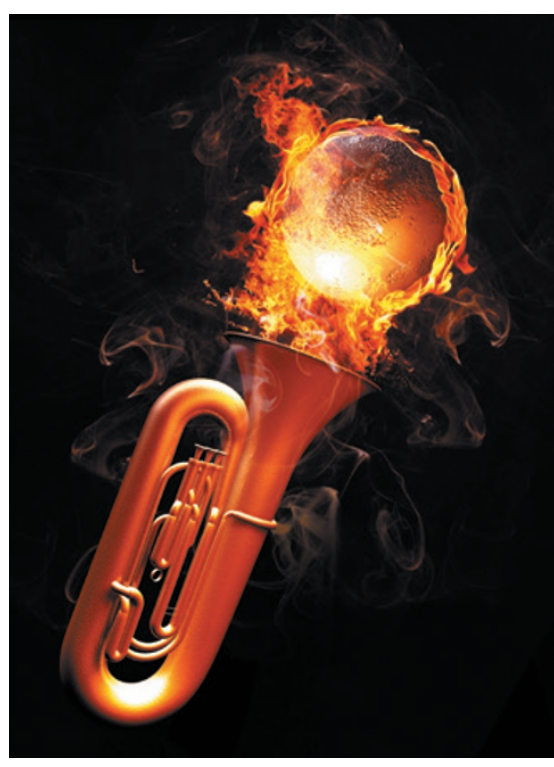

momentarily. A few stray droplets landed on the altar, setting the foolscap alight.

"Hey, you two! No splashing ...! Where was I? Look, I don't have time to argue with you. Did you request a portal to Lucifer or not?"

"I did."

"Lucifer? The Morning Star?"

"I ..."

"The Evening Star?"

"Is that a tabloid or something?"

"Venus?"

"Are you telling me that that molten glob and those choking fumes are from Venus?"

"What else would they be?"

What good was Venus? thought Goodman. He recalled the people who had mocked his quest over the years and considered throwing them into the portal. That would certainly be devilish, but he couldn't quite muster a thirst for vengeance. He had been so busy tracking down the codex that he hadn't had time to acquire any real enemies.

"But what about the contract signed in blood?" asked Goodman. "What about the pitchforks and tormented souls?"

"I ... don't really ..." said the agent of Lucifer. "Could you hold for just a minute?"

Goodman watched the ground smoulder, wondering if he should just take the codex and go home. An iron beach ball bounced by within the swirling haze. Vague shapes $\rightarrow$ NATURE.COM

Follow Futures: @NatureFutures

f go.nature.com/mtoodm galloped after it.
"So sorry to keep you waiting," said the agent of Lucifer upon its return. "We closed down our Earth operations centuries ago, including the guest-worker programme." The agent glanced down at the codex. "It seems that your information is out of date."

Goodman sighed and then coughed as a stray plume of carbon dioxide extinguished a smouldering corner of the notes.

"You're saying you don't want my soul?"

"I'm afraid not. Look, I know we should have been clearer about the policy changes, and I hate to see you leave empty-handed."

The agent's eyes brightened to a pleasant shade of orange. "I know! Some of our historical Earth clients have requested heavy metals. Our factories had a cancelled order from the Ishtar Terra Children's Marching Band. Could I interest you in an oboe made of osmium?"

"No, I don't think..."

"A tuba made of tungsten?"

"No. You really don't want my soul? I figured souls would still be marketable in this day and age. There's so much evil in the world."

"Times change. Back then, we needed someone to help us bring organics and the like back from Earth. Ever since the Oxygen Catastrophe, we'd been short-changed on raw materials, but then you came along, with your city-states and language capacity. We figured rather than letting you waste your potential hitting each other with swords... Anyway, now that we have the aerostats, we get what we need from comets and asteroids."

"Aerostat...?"

"Buoyant craft, about a mile wide. We use them as construction platforms and launch sites."

"You have cloud cities?"

"They're automated, except for the maintenance crew - descendants of our original human workforce. It's far too cold up there for our liking. There's not much up there, now that the new resort is up and running. Probably just pools of liquid water and some overgrown greenhouses, I imagine. I could offer you a job up there, but you'd probably find it boring."

"I was thinking something more along the lines of interplanetary tourism director. If you're going to start up your Earth operations again, you need to rethink your image."

"We do?"

Goodman thumped the codex for emphasis. "Absolutely. First, see if your factories can whip up a big ol' pair of pearly gates."

S. R. Algernon studied fiction writing and biology, among other things, at the University of North Carolina at Chapel Hill. He currently lives in Singapore. 